\title{
EFFICIENCY OF ANAEROBIC DECOMPOSITION OF MANURE FROM CATTLE FED WITH SIDA HERMAPHRODITA SILAGE
}

\begin{abstract}
Magda DUDEK, Department of Environment Engineering, Faculty of Environmental Science, University of Warmia and Mazury, Warszawska str. 117a, 10-720 Olsztyn, Poland, magda.dudek@uwm.edu.pl (corresponding author)

Marcin ZIELIŃSKI, Department of Environment Engineering, Faculty of Environmental Science, University of Warmia and Mazury, Warszawska str. 117a, 10-720 Olsztyn, Poland, marcin.zielinski@uwm.edu.pl

Paulina RUSANOWSKA, Department of Environment Engineering, Faculty of Environmental Science, University of Warmia and Mazury, Warszawska str. 117a, 10-720 Olsztyn, Poland, paulina.jaranowska@uwm.edu.pl

Marcin DĘBOWSKI, Department of Environment Engineering, Faculty of Environmental Science, University of Warmia and Mazury, Warszawska str. 117a, 10-720 Olsztyn, Poland, marcin.debowski@uwm.edu.pl

Cezary PURWIN, Department of Environment Engineering, Faculty of Environmental Science, University of Warmia and Mazury, Warszawska str. 117a, 10-720 Olsztyn, Poland, cezary.purwin@uwm.edu.pl

Maja FIJAŁKOWSKA, Department of Environment Engineering, Faculty of Environmental Science, University of Warmia and Mazury, Warszawska str. 117a, 10-720 Olsztyn, Poland, maja.fijalkowska@uwm.edu.pl

Anna NOWICKA, Department of Environment Engineering, Faculty of Environmental Science, University of Warmia and Mazury, Warszawska str. 117a, 10-720 Olsztyn, Poland, anna.grala@uwm.edu.pl
\end{abstract}

The study aimed to determine the influence of addition of Sida hermaphrodita silage into cattle forage on efficiency of methane fermentation of cattle manure. Efficiency of methane fermentation connected with amount and composition of produced biogas was determined with respirometric tests. Methane fermentation was performed in mesophilic conditions with initial organic compounds loading of $5 \mathrm{~g} \mathrm{VS} /\left(\mathrm{dm}^{3} \cdot \mathrm{d}\right)$. The study was divided into two stages. In first stage, substrate in methane fermentation was only cattle manure. In second stage, substrate in methane fermentation was cattle manure and Sida silage. There were three series of experiments in each stage, due to cattle manure was obtained from cattle fed with forage differ in contribution of Sida silage $(0-$ series $1,17 \%-$ series $2,34 \%$ - series 3 ).

In the stage 1, biogas production of $223 \pm 15 \mathrm{~L} / \mathrm{kg} \mathrm{VS}, 247 \pm 8.5 \mathrm{~L} / \mathrm{kg} \mathrm{VS}$ and $231 \pm 18 \mathrm{~L} / \mathrm{kg} \mathrm{VS}$ was noted in the series 1,2 , and 3, respectively. The addition of Sida silage to the cattle forage had no impact on biogas potential of cattle manure. In the stage 2 , the same tendency was observed. No differences in biogas composition between series were also observed. Methane content in biogas was about $60 \%$.

Keywords: biogas, cattle manure, Sida hermaphrodita, anaerobic process

\section{INTRODUCTION}

The development of biogas market is related to sources of lignocellulosic substrates that are not competitive for food crops. These sources are plants that can produce high biomass yield on degraded and light soils. An example of such a plant is the Virginia mallow or Virginia fanpetals (Sida hermaphrodita Rusby) (Borkowska and Styk, 2006, Barbosa et al. 2014) that belong to genus Sidia, including annual and perennial plants, and shrubs. Sida hermaphrodita cultivation is successful on all soil types, the only condition for biomass growth is sufficient humidity. This plant grows even on chemically degraded areas, landfill sites subjected to reclamation, excavated heaps, slopes of eroded land, or on land excluded from agricultural use (Borkowska and Molas, 2013).

The biomass of Virginia mallow has found wide possibilities of application. Sida might be used as a forage and energy source. Moreover, Sida biomass has been used in a pulp and paper industry. Due to high protein content (20\%), Sida might be used as a cattle feed. It is eagerly eaten by sheep, rabbits, pigs, and cows. Silage of Sida hermaphrodita is easy to prepare. Leaves, which account for about $50 \%$ of the weight, accumulate a large amount of vitamin $\mathrm{C}$, carotene and lipids. The Sida biomass is also characterized by a relatively high content of calcium and phosphorus. Considering the chemical composition, Sida is similar to lucerne (Giwa, 2017). The advantage of Sida cultivation is its use for several years, not only in agricultural areas, but also in wasteland or degraded areas. Biomass of Sida might be characterized by the availability of different moisture content of the biomass, depending on the demand (Borkowska and Molas, 2012). If Sida is harvested in the form of green fodder (late spring harvest), the biomass can be ensiled and served as an animal

Copyright (C) 2017 The Authors. Published by Aleksandras Stulginskis University. This is an open-access article distributed under the terms of the Creative Commons Attribution License (CC-BY 4.0), which permits unrestricted use, distribution, and reproduction in any medium, provided the original author and source are credited. 
feed or substrate for a biogas plant (Zieliński et al. 2017). The biomass collected in dried form (harvest in winter) can be used in various ways, for example in direct combustion, processing into briquettes or pellets.

The aim of this study was to determine the efficiency of biogas production from manure from cattle fed with Sida hermaphrodita silage. The influence of addition of Sida silage to the forage on biogas production from dairy cow manure was tested.

\section{METHODOLOGY}

The studies about the influence of addition of Sida hermaphrodita silage on efficiency of anaerobic digestion of cow manure was performed on laboratory scale. Characteristics of substrates used in the experiment is presented in Table 1. The characteristic and chemical composition of the forage is presented in Table 2.

Table 1. Characteristics of substrates used in the experiment

\begin{tabular}{|c|c|c|c|c|c|c|c|c|}
\hline & TS [\%] & $\mathrm{SS}[\% \mathrm{Ts}]$ & $\begin{array}{c}\mathrm{VS} \\
{[\% \mathrm{TS}]}\end{array}$ & $\begin{array}{c}\mathrm{CP} \\
{[\% \mathrm{TS}]}\end{array}$ & $\begin{array}{c}\mathrm{EE} \\
{[\% \mathrm{Ts}]}\end{array}$ & NDF [\% $\%$ Ts] & ADF [\% $\%$ Ts] & ADL [\% \\
\hline Sida silage & 16,0 & 10,14 & 89,86 & 19,26 & - & 43,71 & 32,71 & - \\
\hline Cattle manure ( $0 \%$ silage) & 12,91 & 14,51 & 85,49 & 0,29 & 0,95 & 57,89 & 40,56 & 32,88 \\
\hline $\begin{array}{c}\text { Cattle manure (17\% } \\
\text { silage) }\end{array}$ & 15,25 & 15,73 & 84,27 & 033 & 1,43 & 57,18 & 43,08 & 34,32 \\
\hline $\begin{array}{c}\text { Cattle manure }(34 \% \\
\text { silage) }\end{array}$ & 14,20 & 14,80 & 85,20 & 0,48 & 1,94 & 48,70 & 37,87 & 28,97 \\
\hline
\end{tabular}

The experiments were divided on two stages. In the stage I, the bioreactors were fed with the cattle manure. This stage has three series, in each series Sida silage constituted in cow diets of 0, 17 and 34\%, respectively. In the stage II, the bioreactors were fed with the cattle manure and Sida silage in a 1:1 weight ratio.

Table 2. Feed and chemical composition of the experimental diets

\begin{tabular}{|c|c|c|c|}
\hline & Control & Sida low & Sida high \\
\hline \multicolumn{2}{|c|}{ Feed composition (\%DM) } \\
\hline Maize silage & 35 & 34.4 & 34.4 \\
\hline Sida silage & - & 17 & 34 \\
\hline Alfalfa silage & 35 & 17 & 29.4 \\
\hline Concentrate & 30 & 29.4 & 2.1 \\
\hline Straw triticale & \multicolumn{2}{|c|}{} \\
\hline \multicolumn{2}{|c|}{ Chemical composition (g/kg DM) } \\
\hline DM (g/kg FM) & 432.6 & 345.6 & 283.6 \\
\hline OM & 930.2 & 931.4 & 932.1 \\
\hline CP & 154.2 & 153.0 & 354.1 \\
\hline EE & 28.8 & 32.6 & 395.4 \\
\hline ANDF & 392.0 & 397.9 & 231.7 \\
\hline
\end{tabular}

FM - fresh matter; DM - dry matter; OM - organic matter; CP - crude protein; EE - ether extract; aNDF - neutral detergent fibre assayed with heat stable amylose; $\mathrm{ADF}$ - acid detergent fibre

The study used the Methane Potential Analysis Tool AMPTS II Bioprocess Control. This device is used to measure the flow of biomethane, produced during anaerobic digestion from biodegradable substrates.

The device consisted of three subunits. The main component was a bioreactor placed in a water bath that maintains constant temperature of the process. Methane fermentation was carried out under mesophilic conditions at $38^{\circ} \mathrm{C}$. The bioreactors had volume of $500 \mathrm{~mL}$. The reaction chambers were connected to the multifunctional agitation system. Mixing in the reactor run for 30 seconds each 10 minutes at $100 \mathrm{rpm}$. Another element was the biogas flow measurement system, which was a water reservoir with cell sensors. Each reaction chamber corresponded to one measuring cell that by builtin motion sensors, enabled for an automatic measurement of the amount of biogas produced. The data collection system was used that display and control the results during the experiment.

The applied method determines the activity of anaerobic sludge, the susceptibility of substrates to biodegradation and the amount of gaseous metabolites of microorganisms. The device continuously recorded the total and instantaneous biogas production value. In each of the experiment series, the reactors were inoculated with an anaerobic sludge derived from a fermentation reactor operating on a semi-technical scale, the input of which was Sida silage and cattle manure. The inoculum was mixed with the test substrates in a 5:1 dry weight ratio. In order to provide anaerobic conditions at the beginning of the experiments, a continuous flushing of pure nitrogen through the sludge was done.

\section{Analytical methods}

The concentration of dry mass, organic and mineral dry mass was determined with gravimetric method. This method include evaporation of the sample, drying of the residue at temperature of $105^{\circ} \mathrm{C}$ to a constant weight, and then repeating the steps with taking into account the burning of the dry residue in temperature of $550^{\circ} \mathrm{C}$. 
The gas for quality analysis was taken from the reactors by a gas-tight syringe. The reactors were fitted with valve plugs. The volume of $5 \mathrm{~mL}$ was collected and the composition and percentage were analyzed by GC Agillent 7890 A. The chromatograph was equipped with a thermoconductor detector (TCD). The percentage of the following biogas components was determined: $\mathrm{CH}_{4}$ methane, $\mathrm{CO}_{2}$ carbon dioxide and oxygen $\mathrm{O}_{2}$.

Samples were assayed for dry matter (DM), crude ash, crude protein (CP), ether extract(EE), crude fiber (CF) by standard methods (AOAC, 2005), aNDF by the method proposed by Mertens (2002) and ADF - proposed by Van Soestet al. (1991) using the ANKOM 220 fiber analyzer.

Statistic analysis. The measurements in all series were performed in five replications. After testing for homogeneity of variance with Levene's test, the significance of differences between variants was tested with Tukey's HSD test. Differences were considered significant at $\mathrm{p}<0.05$.

\section{RESULTS AND DISCUSSION}

In the stage I, the cattle manure from cows fed with the forage containing different doses of Sida silage was tested (Table 2). Characteristics of substrates and inoculum before and after anaerobic digestion used in the experiment is presented in Table 3.

Table 3. Characteristics of substrates and inoculum before and after anaerobic digestion used in the experiment

\begin{tabular}{|l|c|c|c|c|c|c|}
\hline & Inoculum and substrate before anaerobic digestion & \multicolumn{1}{c|}{ Inoculum and substrate after anaerobic digestion } \\
\hline & TS [\%] & VS [\% [S] & Hydration [\%] & TS [\%] & VS [\% Ts] & Hydration \%] \\
\hline & 6,4 & 85,04 & 93,6 & 4,6 & 65,83 & 95,4 \\
\hline Series 1 & 7,3 & 87,17 & 92,7 & 4,8 & 65,13 & 95,2 \\
\hline Series 2 & 6,9 & 87,12 & 93,1 & 4,4 & 68,82 & 95,6 \\
\hline Series 3 & 7,7 & 84,59 & 92,3 & 4,5 & 66,00 & 95,5 \\
\hline & 8,2 & 84,69 & 91,8 & 4,6 & 64,99 & 95,4 \\
\hline Series 1 & 7,8 & 85,84 & 92,2 & 4,3 & 70,57 & 95,7 \\
\hline Series 2 &
\end{tabular}

After the methane fermentation process, the organic dry matter was reduced by approx. $25 \%$ in all series of the experiment and the moisture of the substrate and inoculum mixture increased slightly.

The highest biogas production was observed in the series 2 , in which the forage contained $17 \%$ of Sida silage. In this series the biogas production was $247 \pm 8.5 \mathrm{~L} / \mathrm{kg}$ VS. In the series 3, in which the forage contained $34 \%$ of Sida silage, the biogas production was $231 \pm 18 \mathrm{~L} / \mathrm{kg}$ VS. These values were not significantly different. However, these values were comparable with the biogas production from the control reactor, in which Sida silage was not added to the forage.

The fermentation of mono substrate is not applied in agricultural biogas plants. Generally, the reason of this is unfavorable $\mathrm{C} / \mathrm{N}$ ratio and macro or micronutrient deficiencies. The high nitrogen content of cattle manure might cause problems in the use of this substrate as a feedstock for the fermentation chambers. Addition of lignocellulosic substrates improves the biodegradability of manure by altering the physical and chemical properties of the substrate. In order to maintain the process stability and high methane productivity, the substrate should have a C/N ratio between 20 and 35 . The cattle manure has a low C/N ratio of 11-14 (Soheil et al. 2017; Tufaner andAvsar, 2016).

The literature showed that the average methane content of the biogas obtained from manure is about 50-60\% (Noorollahi, 2015), as confirmed by the results of this study. The percentage share of the biogas components was very similar in all series of the stage I, of the study. Methane content ranged from 59 to $61 \%$ (Fig. 1).

In the stage II to the reactors additionally Sida silage was introduced. The same tendency was observed as in the stage I. The highest biogas production was observed in the series 2, in which the forage contained $17 \%$ of Sida silage. The biogas production in this series was $825 \pm 10 \mathrm{~L} / \mathrm{kg}$ VS (Table 4), whereas the biomethane production was $503.25 \pm 12.4$ $\mathrm{L} / \mathrm{kg}$ VS. The control reactor was characterized with biomethane production of $457.5 \pm 8.94 \mathrm{~L} / \mathrm{kg} \mathrm{VS}$. However, in the series 3 , in which the forage contained $34 \%$ of Sida silage, the biomethane production was $475.8 \pm 9.7 \mathrm{~L} / \mathrm{kg} \mathrm{VS}$. Similarly as in the stage I, the biomethane content in biogas was about $61 \%$ (Fig. 1).

Table. 4. Biogas production rate in the successive experimental series.

\begin{tabular}{|c|c|c|c|}
\hline & \multicolumn{3}{|c|}{ Stage I } \\
\hline & Series $1^{a}$ & Series 2a & Series $3^{a}$ \\
\hline $\mathrm{Nl} / \mathrm{kg}$ & $24 \pm 5.0$ & $32 \pm 6.6$ & $28 \pm 3.8$ \\
\hline $\mathrm{Nl} / \mathrm{kgDM}_{\mathrm{DM}}$ & $189 \pm 12.5$ & $215 \pm 14.0$ & $201 \pm 8.8$ \\
\hline $\mathrm{Nl} / \mathrm{kg}_{\mathrm{ODM}}$ & $223 \pm 15.0$ & $247 \pm 8.5$ & $231 \pm 18.0$ \\
\hline \multicolumn{4}{|c|}{ a - no statistically significant differences } \\
\hline & \multicolumn{3}{|c|}{ Stage II } \\
\hline & Series $1^{\mathrm{a}}$ & Series $2^{b}$ & Series $3^{\mathbf{b}}$ \\
\hline $\mathrm{Nl} / \mathrm{kg}$ & $97 \pm 10.6$ & $115 \pm 7.1$ & $109 \pm 8.2$ \\
\hline $\mathrm{Nl} / \mathrm{kg}_{\mathrm{DM}}$ & $645 \pm 12.1$ & $718 \pm 11.5$ & $679 \pm 13.4$ \\
\hline $\mathrm{Nl} / \mathrm{kg}$ ODM & $750 \pm 12.8$ & $825 \pm 10.0$ & $780 \pm 16.4$ \\
\hline
\end{tabular}


Cestonaro et al. (2015) co-fermented the cattle manure with sheep slurry, which contained significantly more lignocellulosic compounds. The studies were performed in several experiments with different percentage content (from $0 \%$ to $100 \%$ ) of manure and slurry. The fermentation was carried out in $6 \mathrm{~L}$ fermenters at temperature of $18.4 \pm 4.1^{\circ} \mathrm{C}$. The authors observed that the addition of the cattle manure higher than 50\% significantly increased the yield of biogas. The highest efficiency of the biogas production was obtained with a substrate consisted of $25 \%$ of the sheep slurry and $75 \%$ of the cattle manure. The biogas production from this substrates was $171 \mathrm{~L} / \mathrm{kg}$ TS that was about $20 \%$ more than in the control sample, in which the substrate was sheep slurry (Cestonaro, 2015).

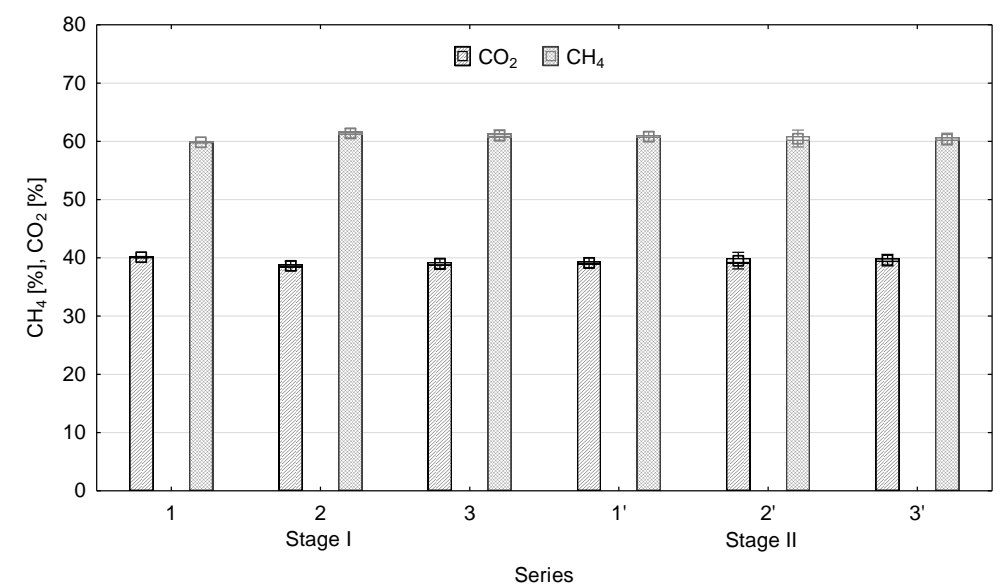

Figure 1. Percentage content of major components of biogas in the successive experimental series.

The co-fermentation of a cattle manure was also carried out by Saidu et al. The authors used the effluent from palm oil production for the enrichment of the substrate and increasing the efficiency of the biogas yield. The process was carried out in a semi-continuous system for more than 20 days. The methane content of the produced biogas was increased of more than twice by co-fermentation. In the control sample (only with cattle manure) the methane content in biogas was $18 \%$, whereas in the sample from co-fermentation it increased to $41 \%$ (Saidu et al. 2013).

The application of co-fermentation and introduction of Sida silage into the reaction chambers had a positive effect on the efficiency of the process. High stability of the technological system was obtained with increased production of the biogas by more than three times.

\section{CONCLUSIONS}

The highest efficiency of the biogas production, with a content of about $60 \%$ of biomethane, might be obtained by co-fermentation of the cattle manure with Sida silage. The yield of biogas production from co-fermentation was in the range of $750 \pm 12.8$ to $825 \pm 10 \mathrm{~L} / \mathrm{kg}$ VS. A slightly higher efficiency of the biogas production was observed from the cattle manure from cows fed with the forage contained $17 \%$ of Sida silage then in the control sample. To obtain higher biogas production it is preferable to co-fermented of the cattle manure with Sida silage. The addition to the forage of the Sida hermaphrodita silage did not significantly affect the biogas production from the cattle manure.

\section{ACKNOWLEDGMENT}

The study was carried out in the framework of the project under program BIOSTRATEG funded by the National Centre for Research and Development No. 1/270745/2/NCBR/2015 "Dietary, power, and economic potential of Sida hermaphrodita cultivation on fallow land"

\section{REFERENCES}

1. A.O.A.C., 2005. Official Methods of Analysis. AOAC, Arlington, VA, USA.

2. Barbosa, D.B.P., Nabel, M., Jablonowski, N.D. 2014. Biogas-digestate as nutrient source for biomass production of Sida hermaphrodita, Zea mays L. and Medicago sativa L. Energy Procedia, Vol. 59, pp. $120-126$. https://doi.org/10.1016/j.egypro.2014.10.357

3. Borkowska, H., Styk, B. 2006. Ślazowiec Pensylwański. Wydawnictwo Akademii Rolniczej w Lublinie, Lublin. [In Polish]

4. Borkowska, H., Molas, R., 2012. Two extremely different crops, Salix and Sida, as sources of renewable bioenergy. Biomass Bioenergy, Vol. 36(1), pp. 234-240. https://doi.org/10.1016/j.biombioe.2011.10.025

5. Borkowska, H., Molas, R.2013. Yield comparison of four lignocellulosic perennial energy crop species. Biomass and Bioenergy, Vol. 51, pp. 145-153. https://doi.org/10.1016/j.biombioe.2013.01.017

6. Cestonaro, T., de Mendonça Costa, M.S.S., de Mendonça Costa, L.A., Rozatti, M.A.T., Pereira, D.C., Lorin, H.E.F., Carneiro, L.J. 2015. The anaerobic co-digestion of sheep bedding and P50\% cattle manure increases biogas production and improves biofertilizer quality. Waste Management, Vol. 46, pp. 612-618. https://doi.org/10.1016/j.wasman.2015.08.040

7. Giwa A. 2017. Comparative cradle-to-grave life cycle assessment of biogas production from marine algae and cattle manure biorefineries. Bioresource Technology, Vol. 244, pp. 1470-1479. https://doi.org/10.1016/j.biortech.2017.05.143 
8. Mertens, D.R., 2002. Gravimetric determination of amylase-treated neu-tral detergent fiber in feeds with refluxing in beakers or crucibles:collaborative study. Journal of AOAC International, Vol. 85, pp. 1217-1240.

9. Noorollahi, Y., Kheirrouz, M., Farabi Asl, H., Yousefi, H., Hajinezhad, A. 2015. Biogas production potential from livestock manure in Iran. Renewable and Sustainable Energy Reviews, Vol. 50, pp. 748-754. https://doi.org/10.1016/j.rser.2015.04.190

10. Saidu M., Yuzir A., Salmiati M.R.S., Azman S., Abdullah S. 2013. Influence of palm oil mill effluent as inoculum on anaerobic digestion of cattle manure for biogas production. Bioresource Technology, Vol. 141, pp. 174-176. https://doi.org/10.1016/j.biortech.2013.03.111

11. Soheil A. N., Mohammadi M., Najafpour G. D., Lahijani P. 2017. Anaerobic co-digestion of animal manures and lignocellulosic residues as a potent approach for sustainable biogas production. Renewable and Sustainable Energy Reviews, Vol. 79, pp. 308-322. https://doi.org/10.1016/j.rser.2017.05.137

12. Tufaner F, Avşar Y. 2016. Effects of co-substrate on biogas production from cattle manure: a review. International Journal of Environmental Science and Technology, Vol. 13, pp. 2303-2312. https://doi.org/10.1007/s13762-016-1069-1

13. Van Soest PJ, Robertson JB, Lewis BA 1991: Methods for dietary fiber, neutral detergent fiber and nonstarch polysaccharides in relation to animal nutrition. Journal of Dairy Science, Vol. 74, pp. 3583-3597. https://doi.org/10.3168/jds.S0022-0302(91)78551-2

14. Zieliński M., Dębowski M., Rusanowska P. 2017. Influence of microwave heating on biogas production from Sida hermaphrodita silage. Bioresource Technology, Vol. 245, pp. 1290-1293. https://doi.org/10.1016/j.biortech.2017.08.165 